University of Nebraska - Lincoln

DigitalCommons@University of Nebraska - Lincoln

Textile Society of America Symposium

Proceedings

Textile Society of America

$10-2020$

Arpilleras the Vessels of Chile's Resistance

Soledad Fátima Muñoz

Follow this and additional works at: https://digitalcommons.unl.edu/tsaconf

Part of the Art and Materials Conservation Commons, Art Practice Commons, Fashion Design Commons, Fiber, Textile, and Weaving Arts Commons, Fine Arts Commons, and the Museum Studies Commons

This Article is brought to you for free and open access by the Textile Society of America at DigitalCommons@University of Nebraska - Lincoln. It has been accepted for inclusion in Textile Society of America Symposium Proceedings by an authorized administrator of DigitalCommons@University of Nebraska - Lincoln. 


\title{
Arpilleras the Vessels of Chile's Resistance
}

\author{
Soledad Fátima Muñoz
}

Most historians locate the beginning of the Chilean military dictatorship after the coup d'état that overthrew democratically elected President Salvador Allende on September 11th of 1973. However, for this paper, I will focus on the ideological background that preceded this era and the economic structures that continue to oppress impoverished people in Chile today. Through the history of the arpilleras and subsequently the resistance embroideries created after the 2018 Chilean Feminist Revolution and the Revolt of October 2019, this paper will look into the relationship between Western academic institutions (specifically the University of Chicago) and their role in the implementation of Neoliberalism in Chile. I will be supplementing this essay with interviews from "La Parte de Atrás de la Arpillera" (The Back of the Arpillera), an audiovisual work I made in collaboration with Amaranta Espinoza and Lula Almeyda for my presentation at 2020 Hidden Stories/Human Lives Textile Society of America's Symposium. By weaving into this essay the voices of the makers, I hope to resist a colonial and ethnographic approach to research, move towards a culture of consent and combat the anonymity of arpilleristas (arpillera makers) whose names have been replaced for those of collectors and collections around the world.

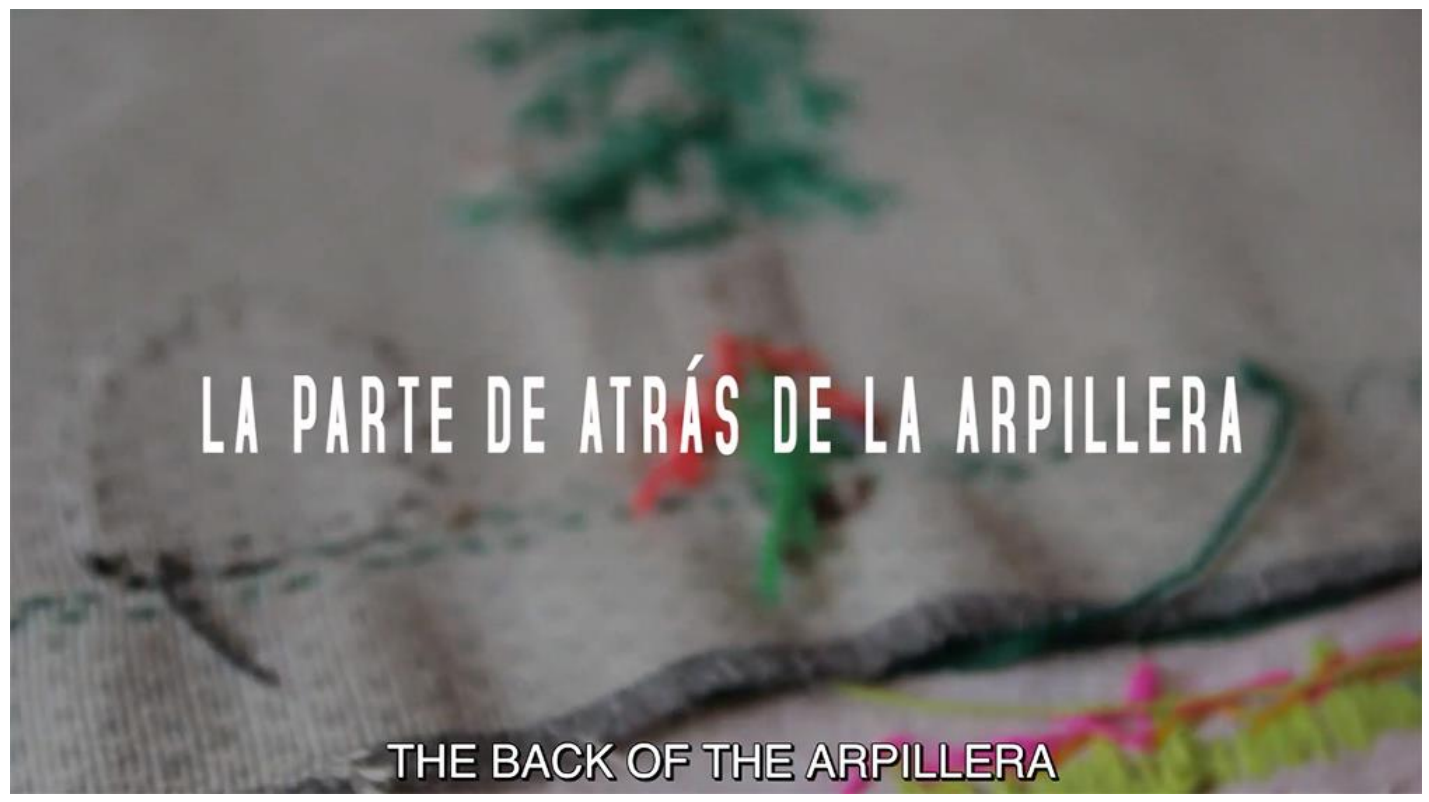

Screen capture from the title frame of the video essay "La Parte de Atrás de la Arpillera" 
Arpilleras are textiles of narrative imagery produced in several Latin American countries and made with applique, embroidery, or lanigrafia techniques on a burlap backing. The term arpillera is the direct translation of the Spanish word for burlap or sackcloth. For this essay, I will focus on the Chilean works made during Augusto Pinochet's dictatorship (1973-1991), which denounced and created international awareness of the atrocities perpetrated by this regime and documented the everyday pains of the impoverished people during the economic crisis in this period. Some of the earliest examples of Chilean arpilleras that precede this era were made in the '60s by artists like Violeta Parra, independent makers, or people in the Isla Negra workshop. They would utilize burlap as a backing because it was a cheap and accessible material used by tailors in patternmaking or to store potatoes. In 1974, Vicaría de la Solidaridad (The Vicariate of Solidarity) hosted one of the first arpillera workshops, founded to support the families of victims of the dictatorship. This organization also helped the arpilleristas export their work to countries in North America and Europe, which enabled them to sustain their families and forge international awareness about their relatives' torture and disappearance, the constant raids to their homes, and family separation via exile. Bélgica Castro, a member of $\mathrm{La}$ Agrupación de Familiares de Detenidos Desaparecidos (Group of Relatives of the Disappeared Detainees) — whose husband Raúl San Martín Barrera was disappeared by agents of Pinochet's regime on October 6th of 1973 - was an early member of this workshop. She compares their meetings at the vicariate to therapy and describes their process of making arpilleras:

We would gather the fabrics we brought from our houses, the craps, and even our relatives' clothes (disappeared) in the middle of the table. Then we would take them, cut 
them and create in those fabrics our experiences, what happened to us daily, the problem of our disappeared, our street outings, and hunger strikes.

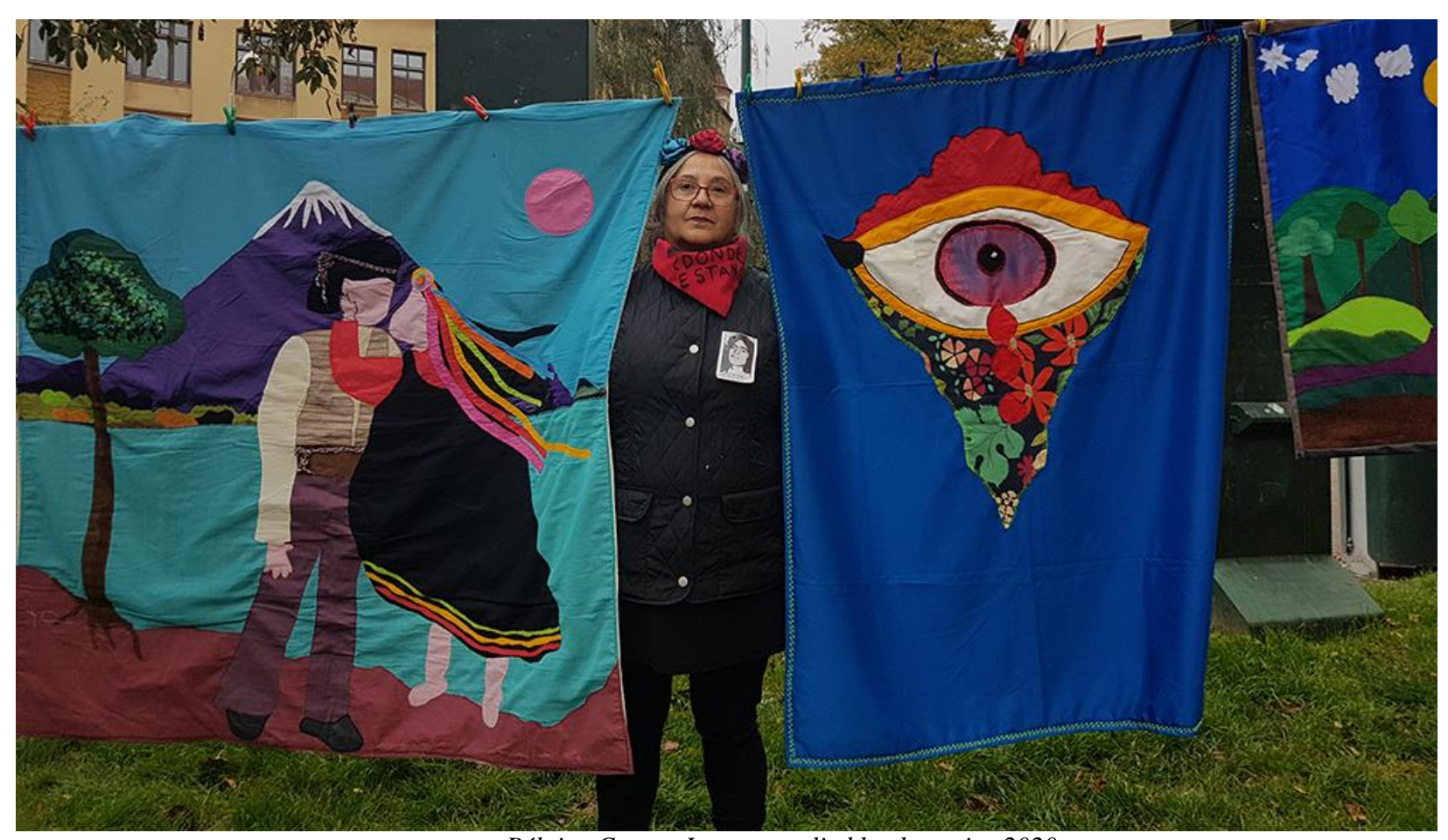

Bélgica Castro. Image supplied by the artist. 2020

Many other workshops started in neighborhoods around Santiago and other Chilean cities. The first one was in Lo Hermida and was created by Maria Madariaga in 1975 to sustain her family through the dictatorship's economic crisis. Though it wasn't easy to get La Vicaria de la Solidaridad to sell their work since it wasn't directly related to the victims of the dictatorship, they ultimately accepted because they depicted the hardships of the Chilean working-class during Pinochet's ruling. Patricia Hidalgo, a member of the Lo Hermida workshop, talks about her process of learning how to make arpilleras:

I will always remember a woman named María Teresa because she was the one who taught me; I think that more than teaching me to embroider, she taught me to see. To know the arpilleras, to feel the arpilleras. I suffered learning, but when I understood what she wanted to teach, what she wanted me to learn, I fell in love. It was different; it was very different. Through the arpilleras we also organized ourselves, we went out to do activities in the street. It made us feel safe because we could talk freely, speak about our things when we got together. 


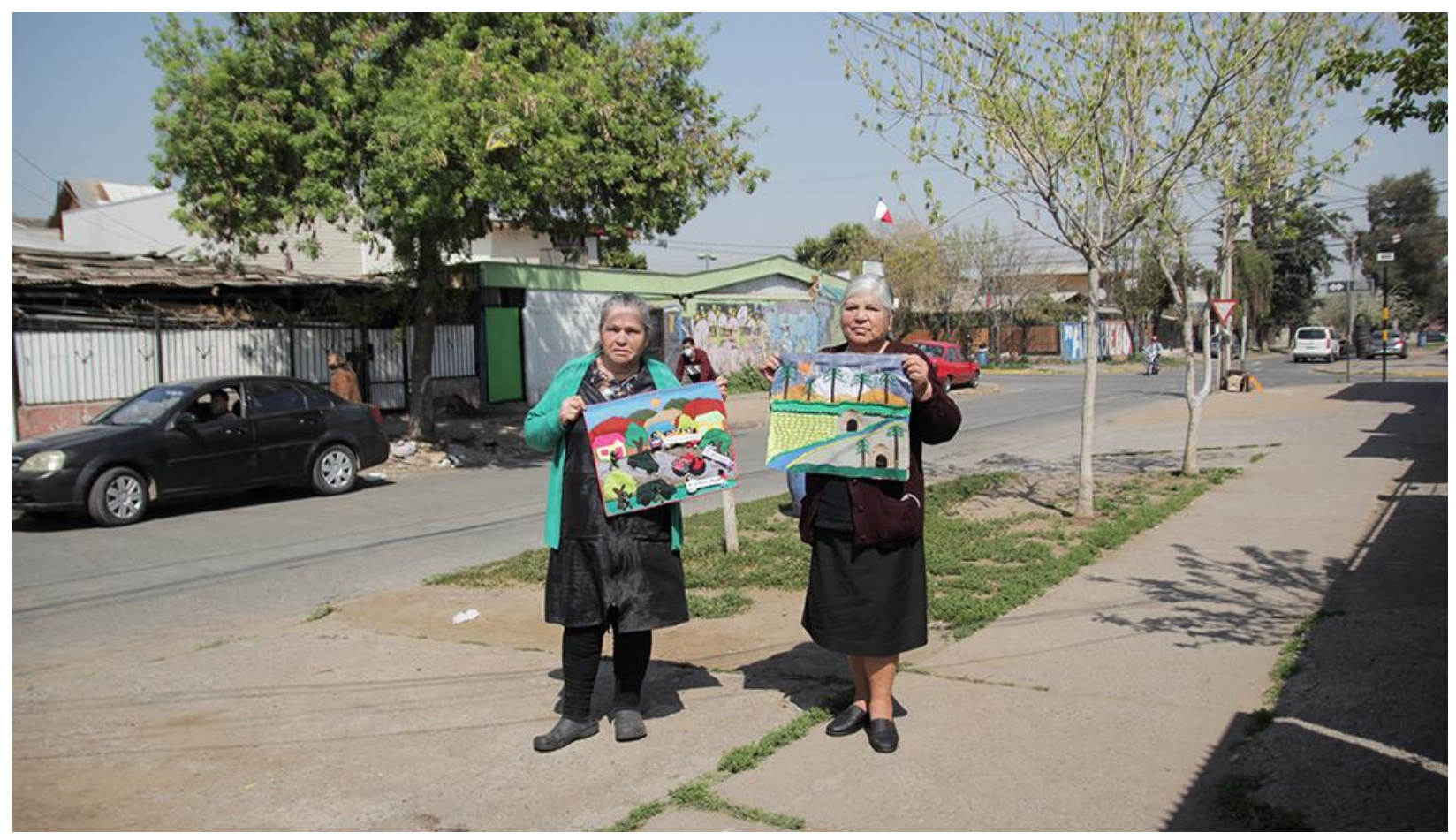

Maria Madariaga and Patricia Hidalgo in Lo Hermida "La Parte Atrás de la Arpillera" archive, 2020

Arpillera making was traditionally gendered, not only because of its relationship to needlework and samplers but also because during the dictatorship, men were incarcerated, tortured, killed, and disappeared at a higher rate, leaving women as the household's primary source of income. Nevertheless, many political prisoners made arpilleras while detained in prisons or concentration camps. Héctor Maturana started using the arpillera as a tool of denunciation after finding a lanigrafia work created by prisoners in the Chacabuco concentration camp. After being accused of violating the State's internal security law and charged with inciting to overthrow the government, Maturana was sentenced to two years in prison. While incarcerated, he founded $E l$ Taller de Arpilleras de Los Presos Políticos de la Cárcel Pública de Antofagasta (The Antofagasta Public Prison's Arpillera Workshop of Political Prisoners). He explains his time in prison:

When we were in prison, we had a routine, which started in the morning with physical activities, then after lunch, we sat down to work. Not all the political prisoners worked making arpilleras, but those who did could exchange ideas and proposals. We would look at a lot of poetry because much of what we did was linked to poetic texts from those years. We wanted to develop a theme that could have an impact on the community. While we were detained, our pieces were exhibited in the city of Antofagasta. Back then, it generated a simple and basic network, but looking at it differently now, the work we were making were focal points of resistance. 


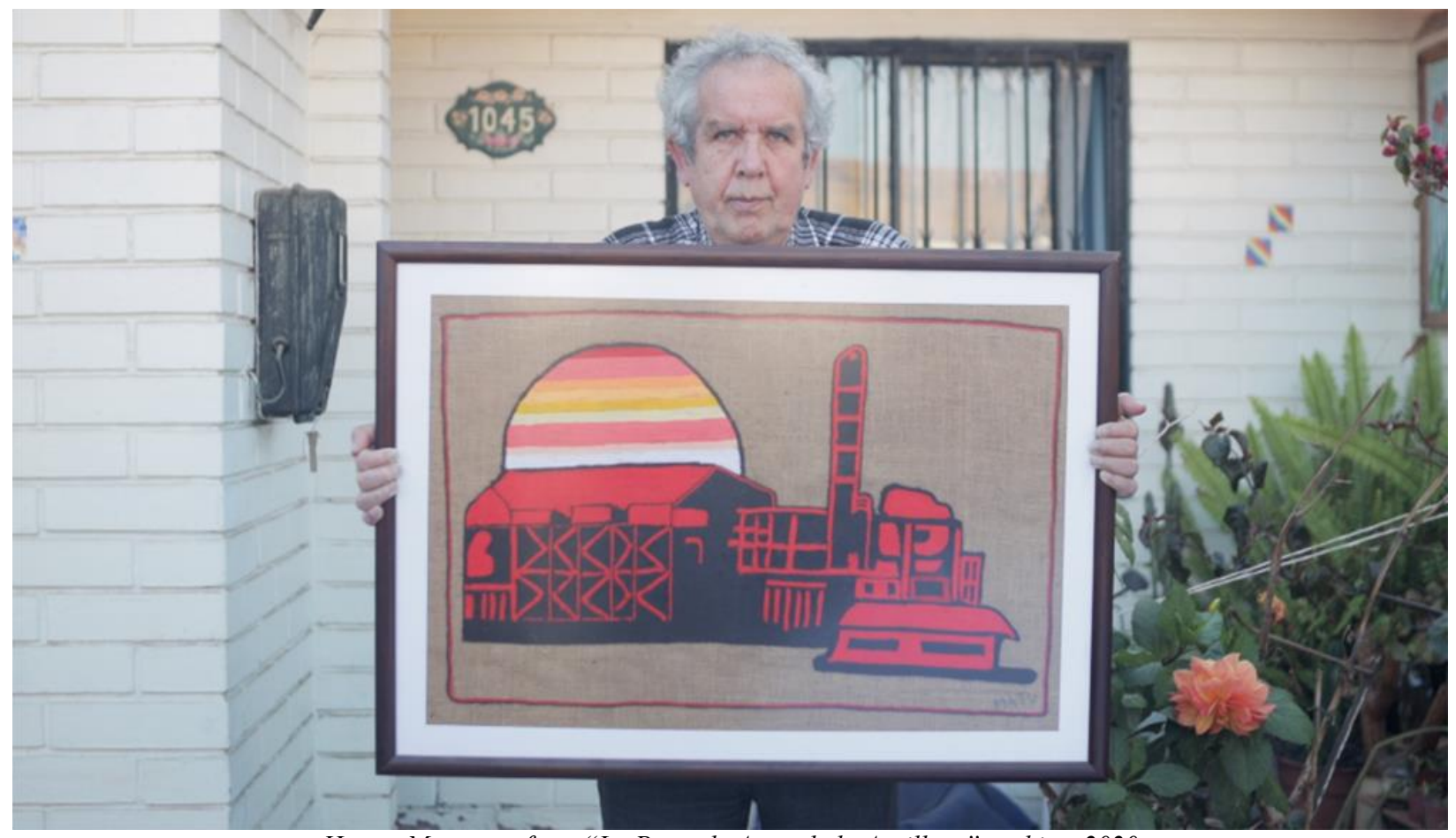

Hector Maturana from “La Parte de Atras de la Arpillera” archive, 2020

The seeds of the economic ideology imposed on Chileans through Pinochet's dictatorship have their origins at the University of Chicago. The documentary Chicago Boys by Carola Fuentes and Rafael Valdeavellano explains that in 1956, with the Ford Foundation's help, the Department of Economics at the University of Chicago signed an exchange agreement with the Universidad Católica de Santiago. The students from the economic elites of Chile traveled to the US to learn Milton Friedman and Arnold Harberger's free-market theories, such as Monetarism and Neoliberalism. The graduates from this program became known as the Chicago Boys. On September 11th of 1973, with the United States' support, the right-wing sector of Chilean politics and General Augusto Pinochet staged a coup d'état against President Salvador Allende's government. Allende was killed on this day by soldiers inside La Moneda (the Chilean government palace). The concepts learned at the Department of Economics at the University of Chicago were passed on to the Junta through a manuscript entitled El Ladrillo (The Brick). Sergio De Castro, a Chicago Boy who wrote this book's prologue, became the dictatorship's economics and treasury minister from 1975 to 1982. André Gunter Frank was an economist who also studied at the University of Chicago. Despite this, he decided to write two open letters to Milton Friedman and Arnold Harberger after observing the inhumane practices perpetuated by the institution, which he compiled and published in the book "Economic Genocide in Chile: Monetarist Theory Versus Humanity. " In these letters, he describes at lengths the intentionality behind economic policies forced on Chileans such as Friedman's "shock treatment." Gunter Frank wrote his second letter in 1976 after seeing the effects of the dictatorship. He includes passages such as the following:

When I was your graduate student, of the "Chile program" in the Department of Economics at the University of Chicago, in which you trained the so-called "Chicago 
Boys," who now inspire and execute the economic policy of the military Junta in Chile. I then went on to summarize the "rationale" of your and the Junta's policy by quoting Harberger's public declarations in Chile and by citing the Junta's official spokesmen and press. Finally, I examined with you the consequences, particularly for the people of Chile, of the application by military-force of this Chicago/Junta policy: political repression and torture, monopolization and sell-out to foreign capital, unemployment and starvation, declining health and increasing crime, all fostered by a calculated policy of political and economic genocide.

During this period, arpilleras were considered political propaganda against the State, and the makers of these textiles were persecuted by the country's military and intelligence agencies. Belgica Castro and Hector Maturana were both political prisoners. María and Patricia from the Lo Hermida workshop recall having to work at night and hide their pieces from their children because they were afraid they could expose them to the authorities.

The Chicago Boys' control on the Chilean population continued growing over time. In fact, in 1980, Pinochet drafted a new Constitution in which the University of Chicago's policies further oppressed the impoverished people of Chile and benefited international markets. This Constitution establishes the privatization of Chilean healthcare, education, pensions, and water supply management. Although the example of the Chicago Boys' ideological interventionism on Chilean soil is an extreme precedent of Western academia's role in perpetuating US imperialism worldwide, it is possible to find vestiges of this colonial gesture throughout history and most definitely concerning the arpilleras. In the article On intellecticide or university driven politics of history, writer Sande Cohen argues that "To historicize is the key linkage: academic/intellectual labor and writing often 'plays for' the future, in which such endeavors require sanitizing a pastpresent so as to select and rank - 'history' serves, and services, present-future institutions, and subjects." The content depicted in the arpilleras is one of the only remaining sources for the descendants of this dictatorship's victims to recover the voice of those silenced by the Department of Economics at the University of Chicago. Therefore, when different forms of academic work about these textiles - mostly written by European and North American scholars - appropriate the arpilleristas resistance and used it as cultural capital for Neoliberal institutions, they perpetuate the silencing of the makers and the colonizer/colonized power dynamic. Some of these works are even published by the University of Chicago Press. 


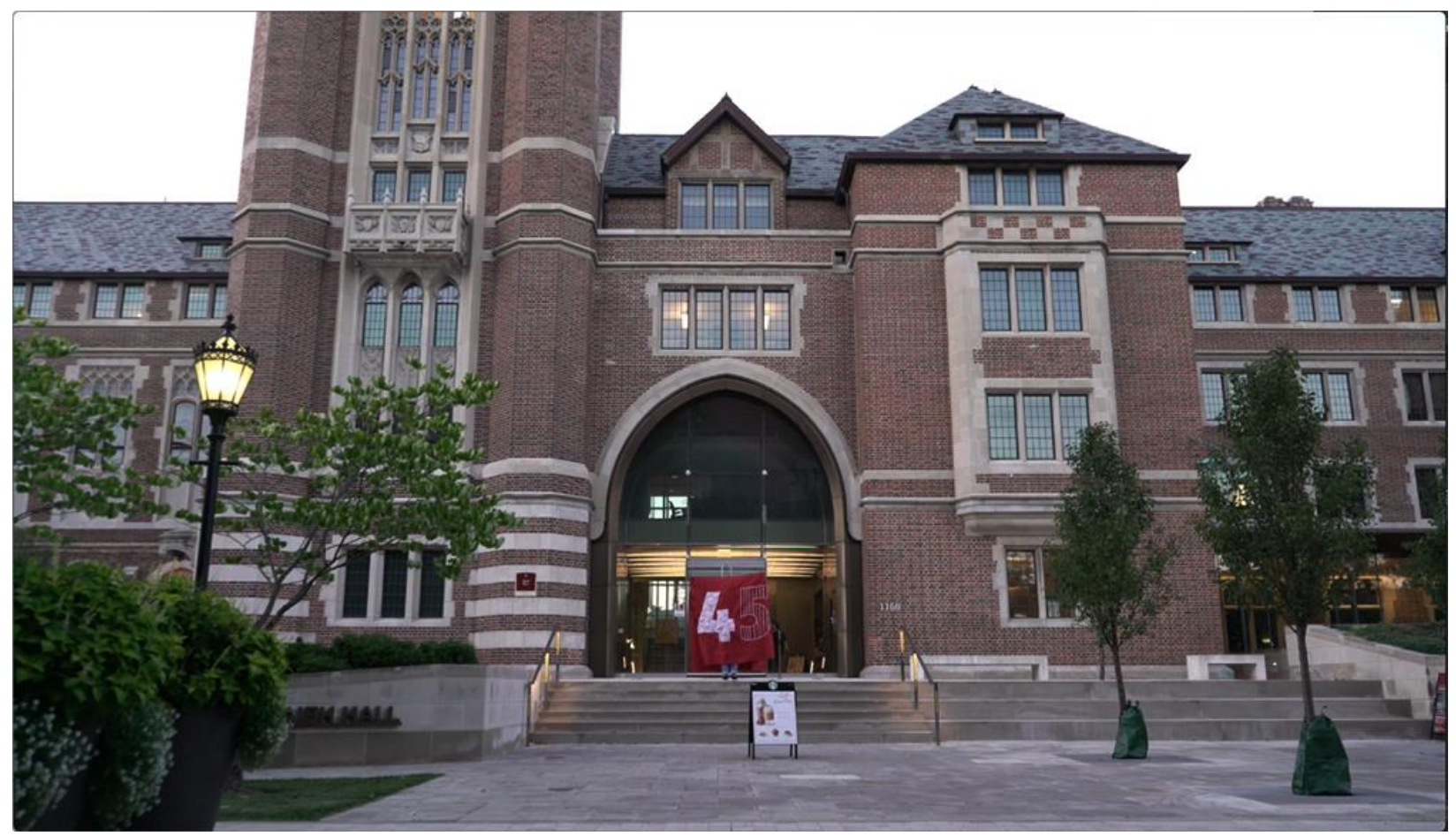

Still from "once del dieciocho" by Soledad Muñoz at the Dpt. of Ecs University of Chicago, 2018

One of the facts our team learned while making La Parte de Atrás de la Arpillera was that the back pocket of the arpilleras was a feature enforced by La Vicaria de la Solidaridad (The Vicariate of Solidarity). This mandatory pocket came as a shock to the team, especially to those of us who have family members who were victims of the dictatorship and grew up around these textiles. It shows the early influence that North American and European consumers had on these textiles and the artists' freedom of expression. Like Belgica Castro, some described the pocket's inclusion as voluntary due to the necessity of staying anonymous. However, Maria Madariaga and Patricia Hidalgo's experience was different. Here is an excerpt of the conversation they had about this topic:

Patricia: Yes, so inside (of the pocket), there was a sheet of notebook paper, and you would write, "I am Patricia... and this is what I want to represent here," but not your full name, nothing.

María: We would go to deliver the arpillera, and we would give it to a person there at the Vicaría (The Vicariate of Solidarity), and that person had to see if the pockets were included or not.

Patricia: I have the impression that every time we had to change something, the suggestions came from outside (internationally). They would say, "We will frame it, so don't do anything to it." I think that many people did not understand what we wanted to convey.

María: Specially the gringos. 
Patricia: Yes, the gringos. So the best way of telling the story was with the pocket. But I think maybe I was always a little rebellious, no, more than a little. I thought the story had to be told here (on the cloth), as you are living it, not as afterward; it's different, I thought, to embroider it than to write it.

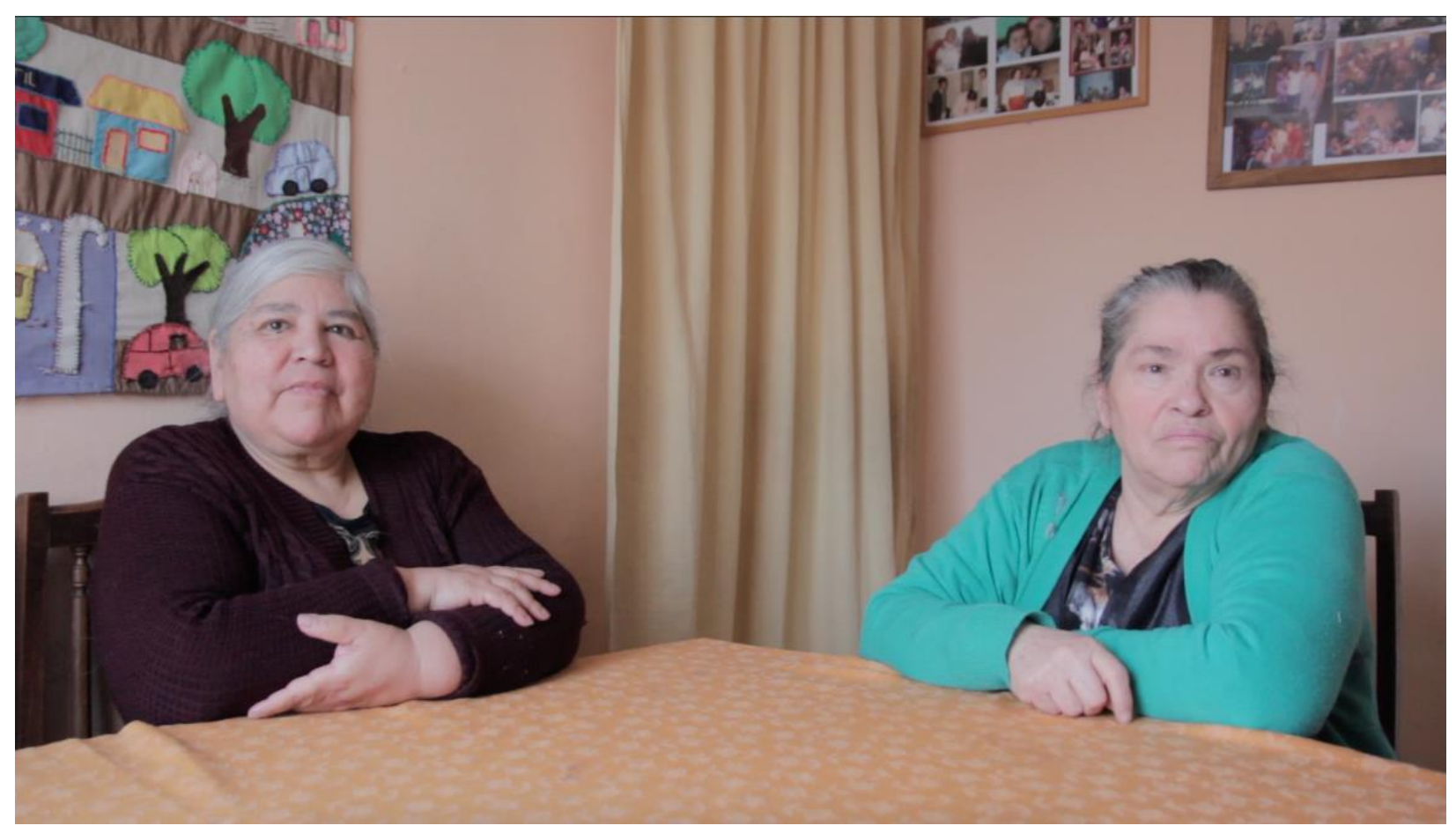

Patricia Hidalgo and Maria Madariaga “La Parte de Atrás de la Arpillera” archive, 2020

The relationship between the arpilleras and Neoliberalism is complicated. Still, over time, we must recognize that seeming acts of benevolence in actuality are acts of violence. The fact that the arpilleras were created as a reaction to an ideological genocide makes them a political object in their inception; they carry a gesture outside of language that can resist Western trains of thought and ideological repression. Even after being objectified by academia, the arpilleras continue to deconstruct hegemonic ideologies because they are witnesses and denouncers of US imperialism worldwide. Purchasing, collecting, exhibiting, or writing about them without a deconstructive anti-capitalist approach perpetuates the makers' oppression. Bélgica Castro, who has been living in exile in Malmö, Sweden, since the dictatorship, is currently in the process of writing a book to honor the arpilleristas that have not been given the credit they deserve. In doing this, she is disrupting the ethnographic nature of research-based colonial writings and replacing it with her embodied perspective.

I did not study; I am not an artist. I am a fighter for social justice. A human rights defender, that is who I am. As a person, I need to write what I lived and my experiences because I can also legitimize those anonymous people who made beautiful arpilleras. 
Yet, nobody knows about their work or what they did. For example, in the Group of Relatives of the Disappeared Detainees, a woman made extraordinary work; her name was Violeta Morales. She was looking for her disappeared brother. She was the teacher, and she was the best arpillerista that the group had. Not much has been said about her or her work. But they talk about the person who took those arpilleras, who appropriated her work, the collector. Because of examples like this, I want to write my book.

The colonial gesture that penetrates this cloth's history profoundly affects the maker. The main concerns we saw repeated in the interviews were around authorship, anonymity, and the appropriation of the arpilleristas' experiences to fit a specific colonial discourse. Thankfully, a new generation of Chilean makers is taking it upon themselves to legitimize these practices and carve a much-deserved space for these makers within society. Daniela Pizarro is a textile Artist who specializes in research and community organizing; she shared with us her thoughts on the contemporary Chilean cultural landscape:

The arpilleras have long been seen as a minor art, and I think this is disrespectful to the work of all the women behind them. So if we do not show the back (of the cloth), we do not show our memory as painful and uneven. We need to get out of this imposture, this idea of official memory, which looks great in the museum but does not look very good in life.

You cannot continue praising anonymity today. Because today, we should be in a different cultural process around the arpilleras since the works no longer need to be anonymous. But I believe that it is convenient for the powerful (people) that the pieces do not have an author, are anonymous, and come from poor, voiceless women. But the arpilleristas have a voice. They are not anonymous. They are the protagonists of the most crucial historical process for which we are still a debt because the bodies (of their family members) have yet to be found. 


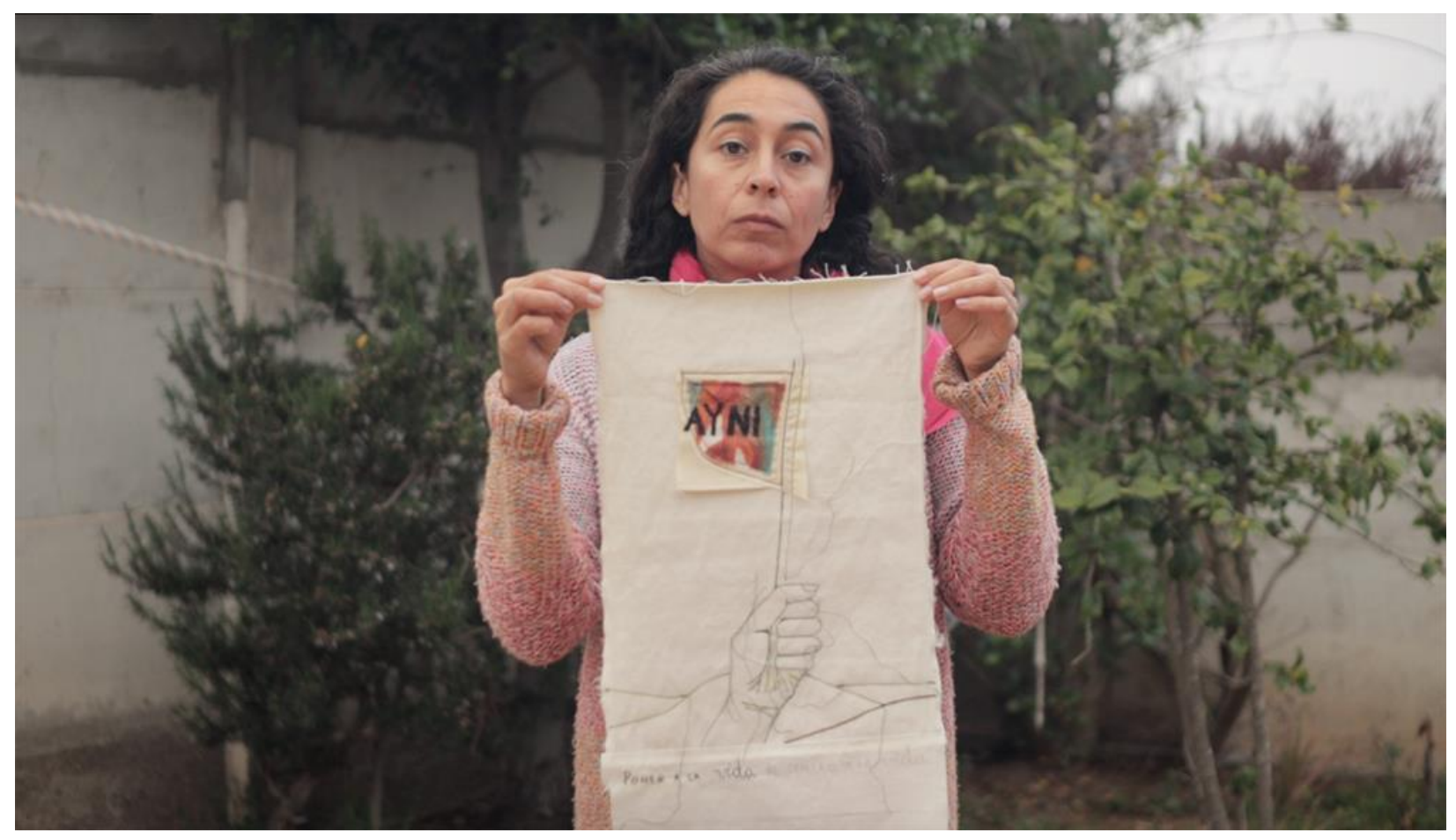

Daniela Pizarro “La Parte de Atrás de la Arpillera” archive, 2020

At the end of the 1980s, massive protests from different social sectors forced the military government of Augusto Pinochet to hold a plebiscite, ultimately returning democracy to Chile. This "new democracy" did not offer the necessary reparations to the dictatorship victims and continued to exercise Neoliberal principles. A silent turmoil was broiling within the country's most impoverished populations.

In October 2019, millions of Chileans took to the streets demanding dignity and the end to the Neoliberal system imposed by the Chicago Boys during the dictatorship. The self-initiated and grassroots organizations that worked hard for years flourished in this environment, developing into territorial assemblies, community dinners, and artistic collectives. But a year after the beginning of this revolt, the state continues to accumulate deaths, imprison protestors, and torture prisoners. In this context, a new generation of resistance embroideries has emerged, and their threads are taking over the streets and online avenues of dissemination. Collectives like Bordadoras Andinas, Anoka, Bordadoras en Resistencia, Frente Textil, Bordando Disidencias, Arpilleras Memorarte, Borda Sin Patrón, Arpilleras Bordando Dignidad, Arpilleras Buena Tela, Pancarta Textil, Hebras de la Memoria, Puntadas Con Hilo Negro, Arpillera Ciudadana, and Resistencia Textil, among many others, are all staples of this new wave of Feminist textile makers. Member's of Colectiva Anoka narrate how their collective started:

Anoka started from the necessity to get together and generate networks of friendship and support among us. We are not only united by our trade and friendship, but rather by our ancestral history. So we decided to embroider a social protest banner for M8 
(International Women's Day). We made it with scraps, we sewed them together, and then we embroidered two banners. That's how the collective was formed. That's how we resist from the most southern place in the world (Punta Arenas). We have something to say, and we do it with the technique our elders taught us.

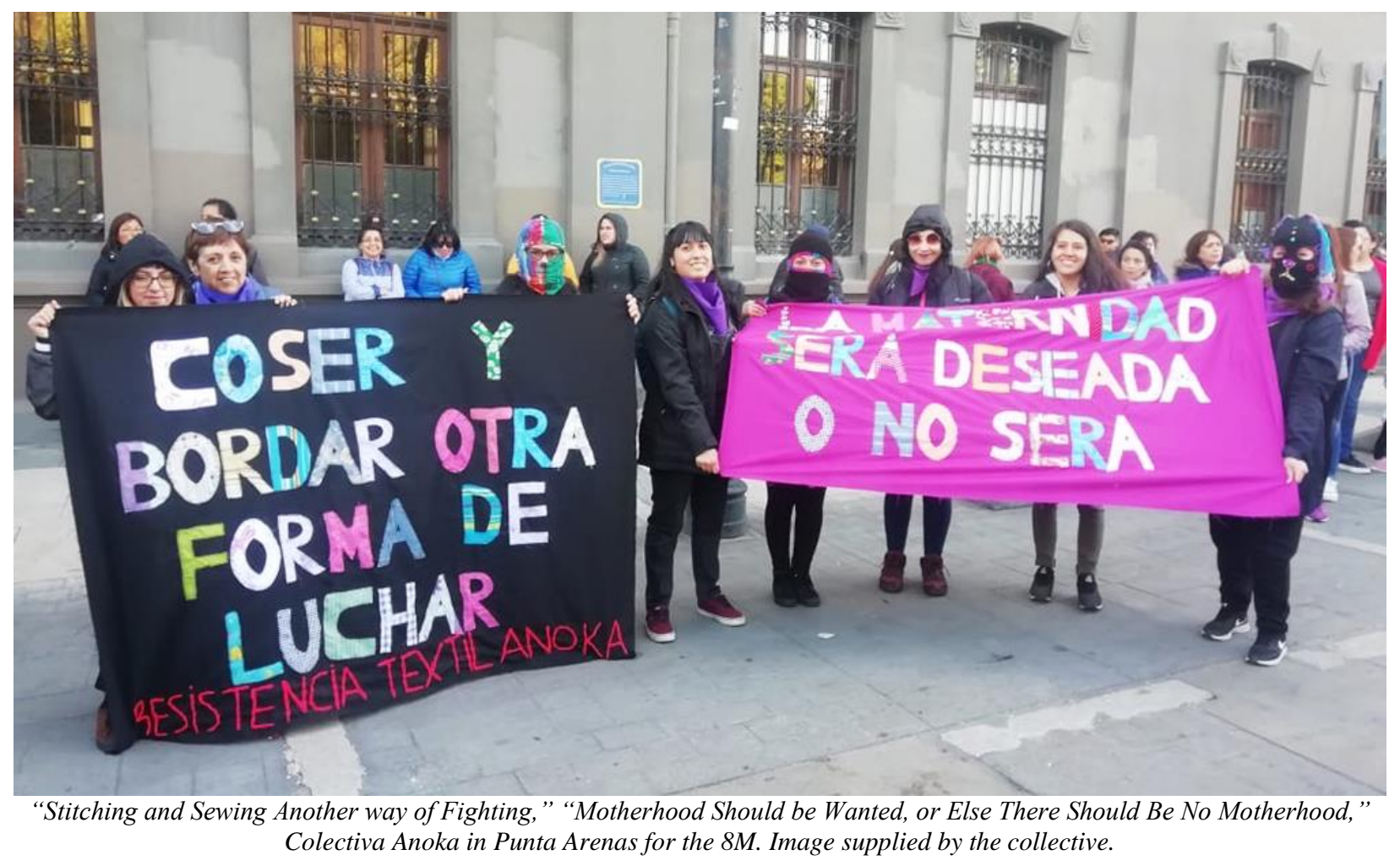

The women from La Colectiva Bordadoras Andinas are a collective from the Akunkawa Valley, one of the regions most affected by a megadrought in Chile's central valley since 2010 . They have been active defenders of this territory organizing political action and forums to bring awareness to the effects of privatizing the water system. This issue - an inheritance from the Chicago Boys - currently favors the private avocado plantations over basic human necessity. When asked why they chose embroidery as a resistance practice, they responded:

It is anti-colonial because it does not respond to a mercantile system where everything has to be fast or mass-produced. It requires time and connection with time and space. The dyes and colors connect us to a territory, and embroidering collectively connects us to one another. We embroider our feelings and bring them out into the public space, which is not expected. Embroidery has always been seen as something fragile that should be done in silence since it traditionally belonged to the domestic space and was associated with something decorative, something that without conflicts. We also subvert the gender roles that schools have imposed on us through aesthetically perfect embroideries. We are not under those set parameters of beauty because we believe that expression has no rules. 


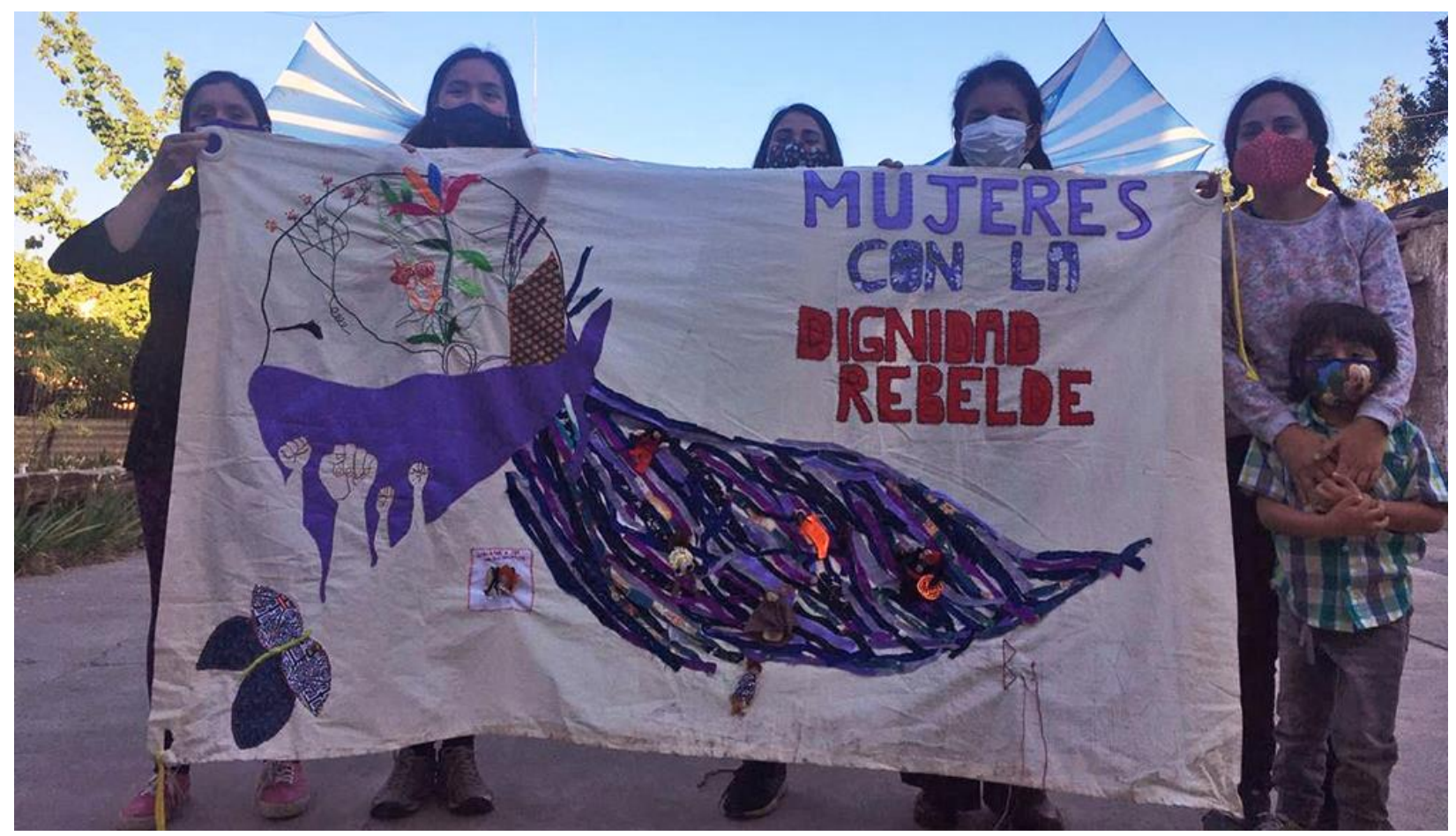

“Women of Rebel Dignity” Colectiva Bordadoras Andinas. Image suplied by the collective, 2020

In August of 2018, my grandfather passed away in Chile. My aunt, who was with him in the hospital, told us that he started screaming in his last moments of consciousness because he thought he was being tortured again. The effects of Pinochet's dictatorship never left him, and, in a way, they will never leave me. It is the reason I was born in exile and has dramatically shaped my worldview. Most of the cultural objects from the people who supported Allende, like archives, vinyls, books, and photographs, were destroyed by the military dictatorship. In protecting the last tangible vestiges of this past, I hope to resist the system that alienated me from my land. Defending the arpilleras from their commodification and consumption by colonial academia - specifically, the works coming from the University of Chicago - allows me to continue the gesture of resistance of my family and add to the momentum of the 2019 revolt so that we can say once and for all never again in Chile. 


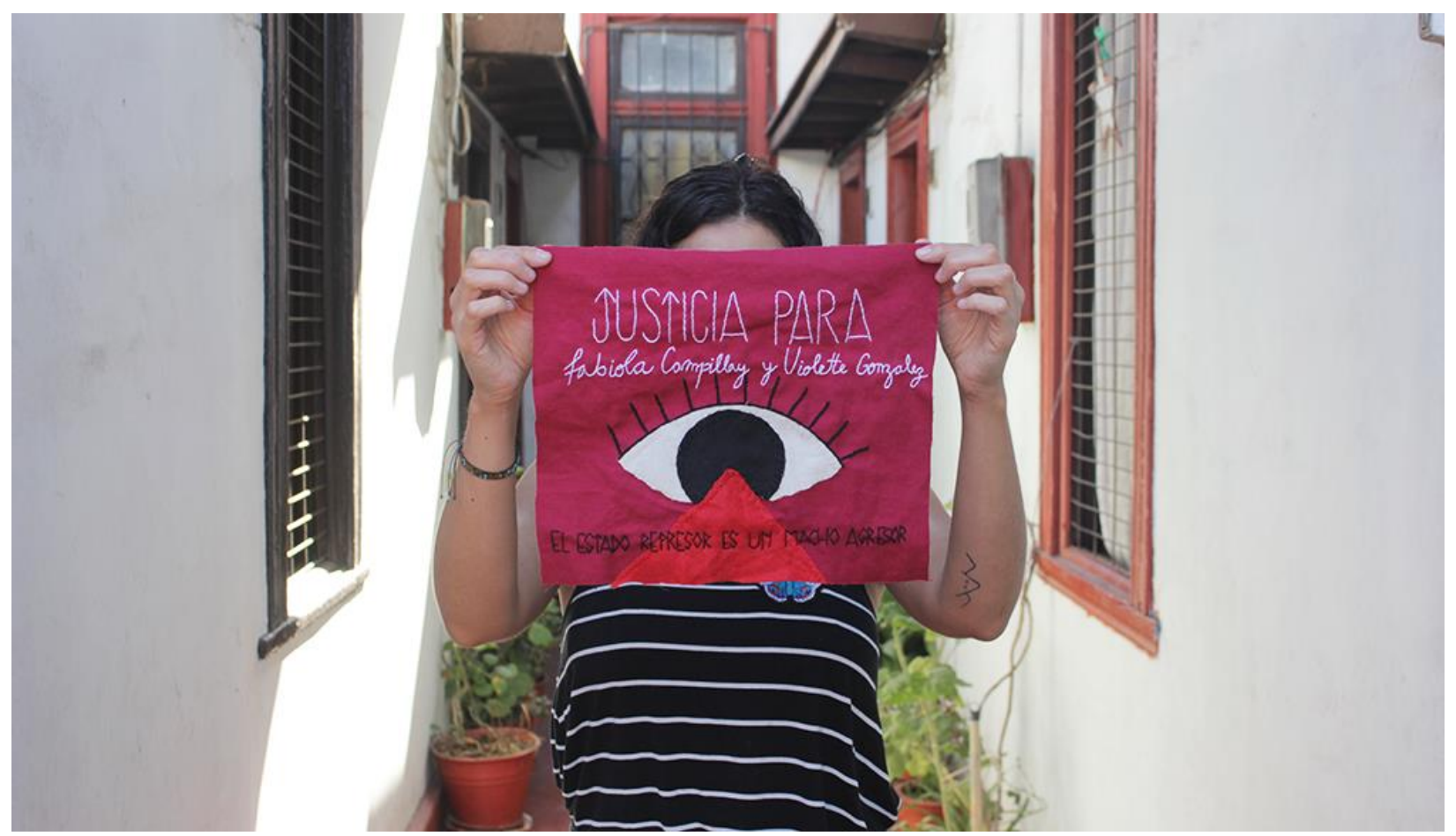

“Justice For Fabiola Campillay y Violette Gonzalez. The Oppresive State is an Agressive Male” Amaranta Espinoza. Image facilitated by the artist, 2019 


\section{Bibliography}

Agamben, Giorgio. Means without End. University of Minnesota Press. Minnesota, 2000. Print.

Agosín, Marjorie. Tapestries of hope, threads of love: the Arpillera movement in Chile. Lanham, MD: Rowman \& Littlefield, 2008. Print.

Cohen, Sande. On intellecticide or university driven politics of history. Rethinking history. Vol. 17, No. 4, 528-547. Routledge, 2003. PDF File.

Gunder Frank, André. Economic Genocide in Chile: Monetarist Theory Versus Humanity. Bertrand Russell Press Foundation Ltd. UK, 1976. Print.

\section{$\underline{\text { Videography }}$}

Chicago Boys. Directed by Carola Fuentes \& Rafael Valdeavellano.Chile: La Ventana Cine, 2016

La Parte de Atrás de la Arpillera. Directed By Lula Almeyda, Amaranta Espinoza and Soledad Muñoz. Santiago - Toronto: Independent, 2020. www.lapartedeatras.com 